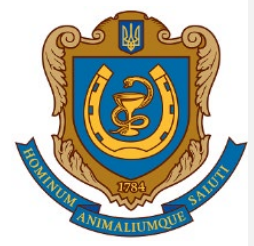

Ukrainian Journal of Veterinary and Agricultural Sciences http://ujvas.com.ua

Stepan Gzhytskyi National University of Veterinary Medicine and Biotechnologies Lviv original article $\mid$ UDC 612.014, 636.4 $\mid$ doi: 10.32718/ujvas3-3.08 Volume 3 Number 3

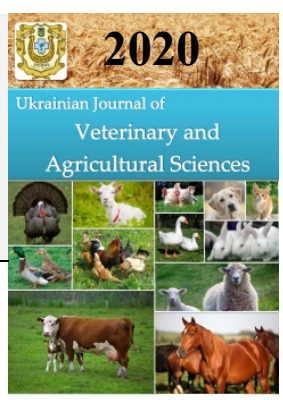

\title{
Hormonal regulation of prooxidant-antioxidant homeostasis in gilts
}

\author{
V. G. Stoyanovskyy ${ }^{1}$, S. O. Usenko ${ }^{2}$, A. M. Shostya ${ }^{2}$, L. M. Kuzmenko², V. G. Slynko², V. S. Tenditnyk ${ }^{2}$ \\ ${ }^{1}$ Stepan Gzhytskyi National University of Veterinary Medicine and Biotechnologies, Pekarska Str., 50, Lviv, 79010, Ukraine \\ ${ }^{2}$ Poltava State Agrarian Academy, Skovorody Str., 1/3 Poltava, 36003, Ukraine
}

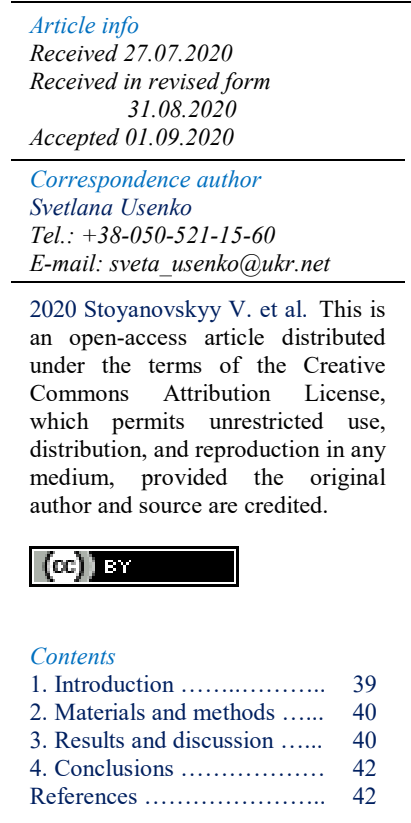

\begin{abstract}
The results of research on the features of cyclic lability of homeostasis in gilts are highlighted. In the experiments it has been used gilts of the Red White belted breed of meat pigs at different phases of the reproductive cycle: luteal phase, estrus, on the 15 th, 20th, 30th, 60th, 90th, 104th, $113^{\text {th }}$ day of pregnancy and in 12 hours after farrowing. The dynamics of the content of thyroid and steroid hormones, as well as the peculiarities of the formation of prooxidant-antioxidant homeostasis were determined in blood serum. It was found out that the amount of steroid hormones in blood of gilts is labile and is determined by the physiological state, namely the onset of estrus, relative to the luteal phase, it is increased the level of thyroxine (30.0\%), triiodothyronine (26.3\%), estradiol-17 $\beta$ (by $22.8 \%, \mathrm{P}<0.01)$ testosterone $(15.2 \%$ ), as well as a decrease in progesterone (by $37.2 \%$ ). Such changes are accompanied by the acceleration of peroxidation processes, xanthine oxidase activity increases, it is increased the content of diene conjugates $(\mathrm{P}<0.05)$ and TBA-active compounds. This is accompanied by a probable increase in the level of antioxidant protection - the activity of superoxide dismutase $(\mathrm{P}<0.05)$, vitamin $\mathrm{A}(\mathrm{P}<0.05)$ and vitamin $\mathrm{E}(\mathrm{P}<0.05)$. During two months of pregnancy, the concentration of thyroxine $(\mathrm{P}<0.05)$, triiodothyronine, progesterone $(\mathrm{P}<0.01)$, testosterone $(\mathrm{P}<0.05)$ and estradiol-17 $\beta$ increases. Such metabolic shifts cause changes in the state of prooxidant-antioxidant homeostasis in the direction of reducing the intensity of peroxidation processes. In gilts before farrow there is a decrease in thyrocoxin, triiodothyronine and progesterone. The intensification of peroxidation was found: the increase in SOD activity $(\mathrm{P}<0.05)$, the dehydroascorbic acid content $(\mathrm{P}<0.05)$, diene conjugates and TBA-active complexes, as well as the decrease in the concentration of reduced glutathione and vitamin $\mathrm{A}(\mathrm{P}<0.05)$ and vitamin $\mathrm{E}(\mathrm{P}<0.05)$. In blood of sows after farrowing, the concentration of thyroxine increases on 1.3 times, triiodothyronine - on 2.7 times, and progesterone and estradiol-17 $\beta$ decreases on 1.8 and 8.7 times, respectively. It was revealed that the intensity of lipid peroxidation processes decreased: DC content by $16.3 \%$ and TBA-active complexes by $13.3 \%$. It was determined that the concentration of ascorbic acid decreased by $32.8 \%$ and vitamin $\mathrm{E}-18.9 \%$.
\end{abstract}

Key words: gilts, reproduction, blood, homeostasis, hormones, antioxidants, pregnancy.

\section{Citation:}

Stoyanovskyy, V. G., Usenko, S. O., Shostya, A. M., Kuzmenko, L. M., Slynko, V. G., \& Tenditnyk, V. S. (2020). Hormonal regulation of prooxidant-antioxidant homeostasis in gilts. Ukrainian Journal of Veterinary and Agricultural Sciences, 3(3), 39-43.

\section{Introduction}

The reproductive cycle of sows consists of a clear alternation of certain phases - proestrus, estrus, pregnancy and the period of sexual rest, due to changes in hormonal background. Among the most sensitive homeostatic constants to changes in the endocrine profile in animals are the processes of peroxidation, which occur with the participation of reactive oxygen forms (AFO) (Usenko et al., 2016; Stupar, 2018; Shostia et al., 2019; Usenko et al., 2020).

It has been found that AFO plays a leading role in ensuring motility, sperm survival and egg maturation (Purdey et al., 2015). With the onset of pregnancy, the mother's body is under the influence of oxidative stress, the prolonged action of which is accompanied by disruption of the development of the placenta, fetus and premature birth (Ogbodo et al., 2014). This encourages the development of targeted antioxidant nutrition programs based on a deep understanding of the mechanism of their specific action (Duhig et al., 2014).
It has been proven the fact that in critical periods of embryonic development, peroxidation processes are accelerated, as a result, the sensitivity of the embryo to AFO damage increases, and its protective capabilities are reduced (Patil et al., 2006). Taking into account that different species of agricultural animals have critical periods, and pigs in particular, some of their features are common. The revealed patterns in pigs can be the basis for creating effective methods to reduce embryonic mortality. Among the important characteristics of pregnancy in animals and humans there is the intensification of metabolism before birth, which indicates the importance of studying the processes of peroxidation and their correction during this period (Atiba et al., 2013).

In this regard, it is promising to clarify the peculiarities of the formation of homeostasis, where the leading role belongs to hormones and prooxidant-antioxidant balance in different periods of the reproductive cycle. This will open the possibility to develop effective methods of regulating the 
reproductive cycle, fertilization, growth and development of fetuses, which will increase the intensity of use of sows.

The purpose of research is to determine the features of hormonal regulation of the formation of prooxidantantioxidant homeostasis in gilts depending on the phases of the reproductive cycle.

To achieve this goal the following tasks are solved:

- the dynamics of the content of steroid and thyroid hormones in blood of gilts during the sexual cycle and pregnancy was determined;

- features of the formation of prooxidant-antioxidant homeostasis in gilts depending on their physiological condition were found out.

\section{Materials and methods}

In the experiments on the principle of analogues it has been used 5 clinically healthy gilts of the Red White-belted breed of meat pigs aged 8 months and with weight of 125$130 \mathrm{~kg}$. The pigs were bled on an empty stomach during different periods of the reproductive cycle: luteal phase, estrus, on the 15th, 20th, 30th, 60th, 90th, 104th, 113th day of pregnancy and in 12 hours after farrowing. The content of thyroxine, triiodothyronine, estradiol- $17 \beta$ and progesterone in blood serum was determined by radioimmunological method, and testosterone - by enzyme-linked immuno- sorbent assay. The state of prooxidant-antioxidant homeostasis (PAG) in blood was studied by the activity of xanthine oxidase (CSO) (Kyseliova et al., 2005), the concentration of diene conjugates (DC) (Havrilov \& Melkorudnaya, 1983), the content of TB compounds (Kaidashev, 1996). The level of antioxidant protection was assessed by the activity of superoxide dismutase (SOD) (Brusov et al., 1976), catalase activity (CT) (Velichko et al., 2009), the content of reduced glutathione (Shabunin, 2010), ascorbic and dehydroascorbic acids(ADAA ) (Kaidashev, 1996), the content of vitamin A and vitamin $\mathrm{E}$ (Rybalko, 2005).

\section{Results and discussion}

\section{Results}

Experimental data show the fact that in blood of cycling gilts in the estrus phase, compared with luteal one, there was a significant restructuring of metabolic processes, especially hormonal background (Table 1). Thus, during sexual arousal, it has been determined an increase in the amount of thyroxine and triiodothyronine by 33.0 and $26.3 \%$, respectively. The most pronounced changes in this period were characteristic for sex hormones: the concentration of progesterone decreased by $37.2 \%$ and testosterone by $15.2 \%$, and estradiol $17 \beta$ increased by $22.8 \%(\mathrm{P}<0.01)$.

\section{Table 1}

Dynamics of the content of hormones in blood serum of the Red White-belted breed of meat gilts during the reproductive cycle, $M \pm m(n=10)$

\begin{tabular}{|c|c|c|c|c|c|c|c|c|c|}
\hline \multirow{3}{*}{ Hormones } & \multicolumn{9}{|c|}{ Phases of the reproductive cycle } \\
\hline & \multirow{2}{*}{ Luteal } & \multirow{2}{*}{ Estrus } & \multicolumn{6}{|c|}{ Pregnancy days } & \multirow{2}{*}{$\begin{array}{l}12 \text { hours after } \\
\text { farrowing }\end{array}$} \\
\hline & & & 15 th & 30 th & 60 th & 90th & 104th & 113th & \\
\hline Thyroxine, nmol/1 & $\begin{array}{r}36.34 \pm \\
5.46\end{array}$ & $\begin{array}{c}48.42 \pm \\
5.11\end{array}$ & $\begin{array}{r}50.43 \pm \\
7.39\end{array}$ & $\begin{array}{r}61.20 \pm \\
5.74^{*}\end{array}$ & $\begin{array}{r}55.52 \pm \\
6.47^{*}\end{array}$ & $\begin{array}{r}36.98 \pm \\
4.92\end{array}$ & $\begin{array}{r}34.46 \pm \\
3.38\end{array}$ & $\begin{array}{r}29.07 \pm \\
2.76\end{array}$ & $\begin{array}{r}36.52 \pm \\
3.97\end{array}$ \\
\hline $\begin{array}{l}\text { Triiodothyronine, } \\
\mathrm{nmol} / 1\end{array}$ & $\begin{array}{r}0.95 \pm \\
0.10\end{array}$ & $\begin{array}{r}1.14 \pm \\
0.12\end{array}$ & $\begin{array}{r}1.28 \pm \\
0.23\end{array}$ & $\begin{array}{r}1.43 \pm \\
0.21\end{array}$ & $\begin{array}{r}1.35 \pm \\
0.19\end{array}$ & $\begin{array}{r}1.59 \pm \\
0.16^{*}\end{array}$ & $\begin{array}{r}1.45 \pm \\
0.27\end{array}$ & $\begin{array}{r}0.67 \pm \\
0, .08\end{array}$ & $\begin{array}{l}1.84 \pm \\
0,22 * *\end{array}$ \\
\hline $\begin{array}{l}\text { Progesterone, } \\
\mathrm{nmol} / 1\end{array}$ & $\begin{array}{r}32.10 \pm \\
4.66\end{array}$ & $\begin{array}{r}20.15 \pm \\
3.71\end{array}$ & $\begin{array}{r}39.53 \pm \\
3.73\end{array}$ & $\begin{array}{r}52.21 \pm \\
3.13 * *\end{array}$ & $\begin{array}{l}70.74 \pm \\
10.89 * *\end{array}$ & $\begin{array}{l}82.33 \pm \\
8.19 * * *\end{array}$ & $\begin{array}{l}85.41 \pm \\
5.62 * * *\end{array}$ & $\begin{array}{r}90.97 \pm \\
8.54 * *\end{array}$ & $\begin{array}{r}50.69 \pm \\
7.05\end{array}$ \\
\hline $\begin{array}{l}\text { Testosterone, } \\
\mathrm{nmol} / \mathrm{l}\end{array}$ & $\begin{array}{r}5.48 \pm \\
0.61\end{array}$ & $\begin{array}{r}4.65 \pm \\
0.74\end{array}$ & $\begin{array}{r}6.09 \pm \\
0.97\end{array}$ & $\begin{array}{r}5.83 \pm \\
0.79\end{array}$ & $\begin{array}{r}10.28 \pm \\
1.57^{*}\end{array}$ & $\begin{array}{r}10.77 \pm \\
1.09 * *\end{array}$ & $\begin{array}{r}8.15 \pm \\
0.74 *\end{array}$ & $\begin{array}{r}6.80 \pm \\
0.79\end{array}$ & $\begin{array}{r}5.82 \pm \\
0.63\end{array}$ \\
\hline $\begin{array}{l}\text { Estradiol-17 } \beta \text {, } \\
\mathrm{nmol} / 1\end{array}$ & $\begin{array}{r}0.14 \pm \\
0.02\end{array}$ & $\begin{array}{r}0.32 \pm \\
0.05 * *\end{array}$ & $\begin{array}{r}0.42 \pm \\
0.06^{* * *}\end{array}$ & $\begin{array}{l}0.33 \pm \\
0.06^{* *}\end{array}$ & $\begin{array}{r}0.52 \pm \\
0.17\end{array}$ & $\begin{array}{r}1.62 \pm \\
0.33 * *\end{array}$ & $\begin{array}{r}3.75 \pm \\
0.69 * * *\end{array}$ & $\begin{array}{r}5.41 \pm \\
0.60 * * *\end{array}$ & $\begin{array}{r}0.83 \pm \\
0.11 * * *\end{array}$ \\
\hline
\end{tabular}

These changes in the hormonal background were accompanied by a significant restructuring of metabolic processes in the direction of accelerating the course of peroxidation. This is confirmed by a slight increase in the activity of the prooxidant enzyme - CSO, which significantly accelerated the hemolysis of erythrocytes by $10.8 \%$ (Table 2 ). Such changes are accompanied by an increase in the content of DC in $2.3(\mathrm{P}<0.05)$ and TBA-active complexes in 1.4 times. At the same time, there was an acceleration of the functional activity of antioxidant enzymes: SOD by $36.8 \%$ $(\mathrm{P}<0.05)$ and a decrease in $\mathrm{CT}-51.3 \%(\mathrm{P}<0.05)$. During this period it was found out the fact that there was a significant use of reduced glutathione by $25.7 \%$. It was found that the significant accumulation of vitamin $\mathrm{A}$ in blood on 1.6 times $(\mathrm{P}<0.05)$, vitamin $\mathrm{E}-$ on $1.7(\mathrm{P}<0.05)$, ascorbic and dehydroascorbic acids, respectively, on 1.5 times and 1.4 times $(\mathrm{P}<0.05)$.
The first 15 days of the pregnancy development were characterized by a further intense course of peroxide oxidation processes, which was manifested in the activation of $\mathrm{CT}-39.0 \%$, and a decrease in the functional activity of SOD $-25.3 \%(\mathrm{P}<0.05)$ compared with the estrous phase. This occurred against the background of reducing the concentration of DC - $10.7 \%$, TBA-active complexes by $16.5 \%$, as well as accelerating the use of low molecular weight antioxidants - reducing the content of reduced glutathione and ascorbic acid, respectively, by $15.1 \%(\mathrm{P}<0.05)$ and $45.3 \%$ compared to the estrous phase. Such changes are obviously due to an increase in the amount of steroid hormones: progesterone in 2.01 and estradiol-17 $\beta$ - in 1.3 times compared to the estrous phase. An increase in thyroxine and triiodothyronine concentrations was observed during this period. 
Table 2

The state of PAG in blood of the Red White-belted breed of meat gilts during the reproductive cycle, $M \pm m(n=10)$

\begin{tabular}{|c|c|c|c|c|c|c|c|c|c|}
\hline \multirow{3}{*}{$\begin{array}{l}\text { Indexes } \\
\text { PAG }\end{array}$} & \multicolumn{9}{|c|}{ Phases of the reproductive cycle } \\
\hline & \multirow{2}{*}{ Luteal } & \multirow{2}{*}{ Estrus } & \multicolumn{6}{|c|}{ Pregnancy days } & \multirow{2}{*}{$\begin{array}{l}12 \text { hours after } \\
\text { farrowing }\end{array}$} \\
\hline & & & 15 th & 30th & 60th & 90th & 104th & 113th & \\
\hline $\begin{array}{l}\text { Peroxide resistance of } \\
\text { erythrocytes, } \%\end{array}$ & $\begin{array}{r}16.36 \pm \\
2.84\end{array}$ & $\begin{array}{r}18.50 \pm \\
1.33\end{array}$ & $\begin{array}{r}15.78 \pm \\
1.21\end{array}$ & $\begin{array}{r}15.17 \pm \\
0.99\end{array}$ & $\begin{array}{r}12.35 \pm \\
1.31\end{array}$ & $\begin{array}{r}12.92 \pm \\
1.56\end{array}$ & $\begin{array}{r}10.71 \pm \\
1.12\end{array}$ & $\begin{array}{r}16.23 \pm \\
2.11\end{array}$ & $\begin{array}{r}18.26 \pm \\
1.93\end{array}$ \\
\hline $\begin{array}{l}\text { Xanthine oxidase, } \\
\mathrm{mkkat} / \mathrm{sec} \cdot 1\end{array}$ & $\begin{array}{r}40.63 \pm \\
5.25\end{array}$ & $\begin{array}{r}42.27 \pm \\
3.91\end{array}$ & $\begin{array}{r}44.13 \pm \\
3.01\end{array}$ & $\begin{array}{r}45.38 \pm \\
3.69\end{array}$ & $\begin{array}{r}48.31 \pm \\
3.05\end{array}$ & $\begin{array}{r}39.64 \pm \\
3.23\end{array}$ & $\begin{array}{r}42.41 \pm \\
2.77\end{array}$ & $\begin{array}{r}40.37 \pm \\
3.35\end{array}$ & $\begin{array}{r}39.91 \pm \\
2.57\end{array}$ \\
\hline $\begin{array}{l}\text { Superoxide dismutase, } \\
\text { unit } / \mathrm{ml}\end{array}$ & $\begin{array}{r}0.95 \pm \\
0.12\end{array}$ & $\begin{array}{r}1.38 \pm \\
0.14^{*}\end{array}$ & $\begin{array}{r}1.03 \pm \\
0.09\end{array}$ & $\begin{array}{l}1.57 \pm \\
0.11^{* *}\end{array}$ & $\begin{array}{r}0.99 \pm \\
0.10\end{array}$ & $\begin{array}{r}0.86 \pm \\
0.12\end{array}$ & $\begin{array}{r}1.34 \pm \\
0.16\end{array}$ & $\begin{array}{r}1.56 \pm \\
0.11\end{array}$ & $\begin{array}{r}0.99 \pm \\
0.08\end{array}$ \\
\hline Catalase, & $1.85 \pm$ & $1.46 \pm$ & $2.03 \pm$ & $1.66 \pm$ & $1.36 \pm$ & $1.74 \pm$ & $1.20 \pm$ & $1.14 \pm$ & $1.04 \pm$ \\
\hline $\mathrm{H}_{2} \mathrm{O}_{2} / \min \cdot 1$ & 0.11 & $0.09^{*}$ & 0.08 & $0.04 * * *$ & $0.06^{* *}$ & 0,14 & $0.09 * * *$ & $0.10 * * *$ & $0.12 * * *$ \\
\hline $\begin{array}{l}\text { Reduced glutathione, } \\
\mu \mathrm{mol} / 1\end{array}$ & $\begin{array}{r}0.71 \pm \\
0.08\end{array}$ & $\begin{array}{r}0.53 \pm \\
0.10\end{array}$ & $\begin{array}{r}0.45 \pm \\
0.08^{*}\end{array}$ & $\begin{array}{r}0.41 \pm \\
0.09 *\end{array}$ & $\begin{array}{r}0.32 \pm \\
0.05^{* *}\end{array}$ & $\begin{array}{r}0.35 \pm \\
0.07^{* *}\end{array}$ & $\begin{array}{r}0.29 \pm \\
0.04 * * *\end{array}$ & $\begin{array}{r}0.27 \pm \\
0.05 * * *\end{array}$ & $\begin{array}{r}0.31 \pm \\
0.04 * *\end{array}$ \\
\hline $\begin{array}{l}\text { Ascorbic acid, } \\
\mu \mathrm{mol} / 1\end{array}$ & $\begin{array}{r}14.20 \pm \\
1.86\end{array}$ & $\begin{array}{r}21.44 \pm \\
3.71\end{array}$ & $\begin{array}{r}11.72 \pm \\
1.87\end{array}$ & $\begin{array}{r}15.59 \pm \\
2.24\end{array}$ & $\begin{array}{r}8.73 \pm \\
1.21 *\end{array}$ & $\begin{array}{r}9.25 \pm \\
1.32\end{array}$ & $\begin{array}{r}10.37 \pm \\
1.34\end{array}$ & $\begin{array}{r}7.81 \pm \\
0.83 *\end{array}$ & $\begin{array}{r}5.25 \pm \\
1.08^{*}\end{array}$ \\
\hline $\begin{array}{l}\text { Dehydroascorbic acid, } \\
\mu \mathrm{mol} / \mathrm{l}\end{array}$ & $\begin{array}{r}18.32 \pm \\
1.94\end{array}$ & $\begin{array}{r}25.76 \pm \\
2.14^{*}\end{array}$ & $\begin{array}{r}13.68 \pm \\
1.77\end{array}$ & $\begin{array}{r}17.45 \pm \\
2.43\end{array}$ & $\begin{array}{r}13.37 \pm \\
2.20\end{array}$ & $\begin{array}{r}16.59 \pm \\
2.43\end{array}$ & $\begin{array}{r}10.34 \pm \\
1.71 *\end{array}$ & $\begin{array}{r}11.08 \pm \\
0.94 *\end{array}$ & $\begin{array}{r}12.72 \pm \\
1.10^{*}\end{array}$ \\
\hline $\begin{array}{l}\text { Vitamin } A, \\
\mu \mathrm{mol} / 1\end{array}$ & $\begin{array}{r}1.37 \pm \\
0.18\end{array}$ & $\begin{array}{r}2.23 \pm \\
0.29^{*}\end{array}$ & $\begin{array}{r}2.74 \pm \\
0.35^{*}\end{array}$ & $\begin{array}{r}2.57 \pm \\
0.43^{*}\end{array}$ & $\begin{array}{r}1.95 \pm \\
0.34\end{array}$ & $\begin{array}{r}1.63 \pm \\
0.10\end{array}$ & $\begin{array}{r}1.14 \pm \\
0.09\end{array}$ & $\begin{array}{r}0.87 \pm \\
0.11^{*}\end{array}$ & $\begin{array}{r}0.81 \pm \\
0.17^{*}\end{array}$ \\
\hline $\begin{array}{l}\text { Vitamin E, } \\
\mu \mathrm{mol} / 1\end{array}$ & $\begin{array}{r}0.92 \pm \\
0.13\end{array}$ & $\begin{array}{r}1.58 \pm \\
0.26^{*}\end{array}$ & $\begin{array}{r}1.69 \pm \\
0.20^{*}\end{array}$ & $\begin{array}{r}1.48 \pm \\
0.15^{*}\end{array}$ & $\begin{array}{r}1.36 \pm \\
0.19\end{array}$ & $\begin{array}{r}1.25 \pm \\
0.16\end{array}$ & $\begin{array}{r}1.94 \pm \\
0.10^{* * *}\end{array}$ & $\begin{array}{r}0.53 \pm \\
0.10^{*}\end{array}$ & $\begin{array}{r}0.43 \pm \\
0.09 *\end{array}$ \\
\hline $\begin{array}{l}\text { Diene conjugates, } \\
\mathrm{mmol} / 1\end{array}$ & $\begin{array}{r}1.38 \pm \\
0.29\end{array}$ & $\begin{array}{r}3.17 \pm \\
0.46^{*}\end{array}$ & $\begin{array}{r}2.83 \pm \\
0.52 *\end{array}$ & $\begin{array}{r}2.21 \pm \\
0.44\end{array}$ & $\begin{array}{r}1.86 \pm \\
0.27\end{array}$ & $\begin{array}{r}1.55 \pm \\
0.21\end{array}$ & $\begin{array}{r}2.16 \pm \\
0.28\end{array}$ & $\begin{array}{r}2.12 \pm \\
0.24\end{array}$ & $\begin{array}{r}1.76 \pm \\
0.19\end{array}$ \\
\hline $\begin{array}{l}\text { TBA-active complexes, } \\
\mu \mathrm{mol} / 1\end{array}$ & $\begin{array}{r}15.7 \pm \\
1.62\end{array}$ & $\begin{array}{r}22.31 \pm \\
2.66\end{array}$ & $\begin{array}{r}18.63 \pm \\
1.97\end{array}$ & $\begin{array}{r}12.56 \pm \\
1.79\end{array}$ & $\begin{array}{r}12.41 \pm \\
1.78\end{array}$ & $\begin{array}{r}15.79 \pm \\
1.21\end{array}$ & $\begin{array}{r}12.41 \pm \\
1.72\end{array}$ & $\begin{array}{r}20.6 \pm \\
2.91\end{array}$ & $\begin{array}{r}17.86 \pm \\
2.02\end{array}$ \\
\hline $\begin{array}{l}\text { TBA-active complexes } \\
\text { after incubation, } \mu \mathrm{mol} / 1\end{array}$ & $\begin{array}{r}20.13 \pm \\
1.25\end{array}$ & $\begin{array}{r}23.64 \pm \\
2.81\end{array}$ & $\begin{array}{r}22.28 \pm \\
4.16\end{array}$ & $\begin{array}{r}19.37 \pm \\
2.98\end{array}$ & $\begin{array}{r}14.88 \pm \\
1.89^{*}\end{array}$ & $\begin{array}{r}20.32 \pm \\
3.03\end{array}$ & $\begin{array}{r}19.28 \pm \\
2.07\end{array}$ & $\begin{array}{r}17.71 \pm \\
2.06\end{array}$ & $\begin{array}{r}15.63 \pm \\
1.70\end{array}$ \\
\hline
\end{tabular}

At the end of the first month of pregnancy there was a further increase in the functional activity of the prooxidant enzyme, the generator of reactive oxygen forms - CSO. However, the intensity of peroxide oxidation processes was slightly inhibited, which is confirmed by a decrease in the content of secondary peroxidation products - TBA - active complexes. Excessive levels of generated AFO are inactivated by high SOD activity $(\mathrm{P}<0.05)$. During this period it was noticed that there was a further decrease in the amount of reduced glutathione by $42.3 \%(\mathrm{P}<0.05)$, with a parallel increase in concentrations of ascorbic acid, vitamin A $87.6 \%(\mathrm{P}<0.05)$ and vitamin $\mathrm{E}-60.9 \%(\mathrm{P}<0.05)$ compared with the period of sexual rest.

During the second month of pregnancy relative to the initial period of the experiment it has been found a significant acceleration of metabolic processes in gilts due to an increase in the content of steroid hormones: progesterone in $2.2(\mathrm{P}<0.05)$ and estradiol - in 3.7 times. During this period, there was an increase in CSO activity by $18.9 \%$, which promotes the synthesis of certain biologically active substances, regulating the activity of blood vessels. At the same time there is a decrease in the intensity of lipid peroxidation - a decrease in the content of DC $-34.8 \%$ and TBA complexes $-21.0 \%$, which increases the resistance of erythrocytes to peroxide hemolysis $-24.5 \%$. At the end of the first half of pregnancy, a decrease in the level of the antioxidant defense system was revealed due to a decrease in SOD activity by $13.1 \%$ and an increase in the concentration of vitamin $\mathrm{A}-16.4 \%$ and vitamin $\mathrm{E}-8.1 \%$. Exactly from the 60th to the 90th day of pregnancy of gilts the increase in the amount of progesterone by 1.2 and estradiol-17 $\beta$ was detected by 3.1 times $(\mathrm{P}<0.05)$.

In gilts from the 90th day of pregnancy to farrowing, there was a shift of PAG in the direction of the intensifica- tion of peroxidation, due to the increased activity of SOD by $81.4 \%(\mathrm{P}<0.05)$ and diene conjugates by $35.9 \%$ and TBAactive complexes by $42.0 \%$, as well as a decrease in the concentration of low molecular weight antioxidants: reduced glutathione $-22.9 \%$, vitamin A - $46.6 \%$ and vitamin E $57.6 \%$. Such metabolic changes were accompanied by a decrease in the level of functional activity of the thyroid gland to the secretion of thyroxine by $21.4 \%$ and triiodothyronine $-57.9 \%$, as well as a rapid increase in the concentration of antioxidant - estradiol-17 $\beta$, in 3.3 times $(\mathrm{P}<0.05)$.

In the postpartum period, in 12 hours after farrowing the content of thyroid hormones increased: thyroxine by 1.3 and triiodothyronine by 2.7 times, which is the evidence of their leading role in ensuring adaptation processes in this period for sows and piglets. Exactly in this phase of the reproductive cycle it has been determined a deep hormonal adjustment - a decrease in the concentration of progesterone by 1.8 and estradiol-17 $\beta$ is by 8.7 times. There was a decrease in the indicative indexes of the intensity of lipid peroxidation: DC by $16.3 \%$ and TBA-active complexes by $13.3 \%$. This decrease was accompanied by depletion of the antioxidant defense system: functional activity of CT by $8.8 \%$ and SOD is by $36.5 \%$. Such changes occurred against the background of a decrease in the concentration of ascorbic acid by $32.8 \%$, vitamin $\mathrm{A}$ is by $6.9 \%$ and vitamin $\mathrm{E}$ is by $18.9 \%$.

\section{Discussion}

The obtained research materials indicate that in blood of gilts during the reproductive cycle the change in hormonal background significantly affects the state of PAG. During estrus, in parallel with the increase in the concentration of estradiol-17 $\beta$ and thyroid hormones, the level of CSO, SOD, the amount of DC and TBA-active complexes increased, but the content of reduced glutathione decreased, which indi- 
cates a tense metabolic process and regulatory function of reactive oxygen form (Villamor et al., 2019). With increasing growth of pregnancy, the concentrations of progesterone and estradiol-17 $\beta$ significantly increased, which caused a change in the balance in the functional activity of prooxidant and antioxidant enzymes, which is consistent with the statements of K. Duhig (Duhig et al., 2016), S. O. Ogbodo (Ogbodo et al., 2014), M. S. Purdey (Purdey et al., 2015). With the formation of individual organs and systems of the fetuses and the emergence of its own synthesis of certain hormones in the mother's body there was a slowdown in peroxidation processes - reducing functional activity of SOD, CT and the content of DC and TBA-active complexes. However, the prenatal period was characterized by a significant maximum level of sex hormones and an intensive course of lipid peroxidation, which is confirmed by V. N. Romanenko and I. A. Boiko (Romanenko \& Boiko, 2015), D. N. Mitarev (Mitarev, 2009). At the same time with the change of the phase of the reproductive cycle in the postpartum period there is a shift of homeostatic constants, primarily the content of thyroid and steroid hormones at the level of sexual rest, accompanied by a change in proxidant antioxidant homeostasis in the direction of slowing peroxidation. The generalization of the obtained data testifies to one of the features of the reproductive function of sows the cyclic lability of homeostasis in female pigs, which is characterized by certain periodic fluctuations due to changes in their physiological state, aimed at maintaining the physiological norm of metabolic processes (Kovalenko, 2012). In cycling pigs, the significant lability of prooxidantantioxidant homeostasis is aimed at creating the necessary conditions for fertilization. At the onset of the predominance of pregnancy, the shift of homeostatic constants helps to meet the needs of growing and developing embryos. In the conditions of change of peroxide homeostatic constants in blood of females it is possible to judge a morphofunctional state of genitals and fetoplacental system.

\section{Conclusions}

1. The amount of steroid hormones in blood of gilts is labile and is determined by the physiological state, namely at the onset of estrus, relative to the luteal phase, it is increased the level of thyroxine $(30.0 \%)$, triiodothyronine (26.3\%), estradiol-17 $\beta$ (by $22.8 \%, \mathrm{P}<0.01$ ) testosterone (by $15.2 \%$ ), and it is decreased progesterone (by $37.2 \%$ ). Such changes are accompanied by the acceleration of peroxide oxidation processes, there is the increase of xanthine oxidase activity, there is the increase of the content of diene conjugates $(\mathrm{P}<0.05)$ and TBA-active compounds, too. This is accompanied by a probable increase in the level of antioxidant protection - the activity of superoxide dismutase $(\mathrm{P}<0.05)$, vitamin $\mathrm{A}(\mathrm{P}<0.05)$ and vitamin $\mathrm{E}(\mathrm{P}<0.05)$.

2. During two months of pregnancy, the concentration of thyroxine $(\mathrm{P}<0.05)$, triiodothyronine, progesterone $(\mathrm{P}<0.01)$, testosterone $(\mathrm{P}<0.05)$ and estradiol-17 $\beta$ is increased. Such metabolic shifts cause changes in the state of prooxidant-antioxidant homeostasis in the direction of reducing the intensity of peroxidation processes.

3. In gilts before farrowing there is a decrease in the level of thyrocoxin, triiodothyronine and progesterone. It has been determined the intensification of peroxidation: the increase in SOD activity $(\mathrm{P}<0.05)$, the dehydroascorbic acid content $(\mathrm{P}<0.05)$, diene conjugates and TBA-active complexes, as well as the decrease in the concentration of reduced glutathione and vitamin $\mathrm{A}(\mathrm{P}<0.05)$ and vitamin $\mathrm{E}$ $(\mathrm{P}<0.05)$.

4. In blood of sows after farrowing, the concentration of thyroxine increases in 1.3 times, triiodothyronine is in 2.7 times, and progesterone and estradiol-17 $\beta$ decreases in 1.8 and 8.7 times, respectively. It was revealed that the intensity of lipid peroxidation processes decreased: DC content by $16.3 \%$ and TBA-active complexes by $13.3 \%$. It has been determined that the concentration of ascorbic acid decreased by $32.8 \%$ and vitamin $\mathrm{E}$ by $18.9 \%$.

\section{References}

Atiba, A. S., Niran-Atiba, T. A., Akindele, R. A., Jimoh, A.K., Oparinde, D. P., Dudyemi, B. M., \& Ghazali, M. S. (2013). Effect of Weight Gained In Pregnancy on Lipid Peroxidation Product. Journal of Asian Scientific Research, 3(2), 122-127. URL: http://www.aessweb.com/pdf-files/Jasr-3(2)-122-127.pdf.

Brusov, O. S., Herasimov, A. M., \& Panchenko, L. F. (1976). Vliyaniye prirodnykh inhibitorov radikalnykh reaktsiy na avtookisleniye adrenalina. Byulleten eksperimentalnoy biolohii y medydike, 1, 33-35 (in Russian).

Duhig, K., Chappell, L. C., \& Shennan, A._H. (2016). Oxidative stress in pregnancy and reproduction. Obstet Med, 9(3), 113116. doi: $10.1177 / 1753495 \times 16648495$.

Havrilov, V. B., \& Melkorudnaya, M. Y. (1983). Spektrofotometricheskoe opredeleniye soderzhaniya hydroperekisey lipidov v plazme krovi. Laboratornoe delo, 3 , 33-36 (in Russian).

Kaidashev, I. P. (1996). Posibnyk z eksperymentalno-klinichnykh doslidzhen $\mathrm{z}$ biolohii ta medytsyny. Poltava, 123-128 (in Ukrainian)

Kovalenko, V. F. (2012). Fiziologicheskie aspekty metabolizma v sisteme mat-placenta-plod svini: monografiya. Poltava, 204 (in Russian).

Kyseliova, I. K., Maidaniuk, A. V., \& Imedadze, S. P. (2005). Vyznachennia aktyvnosti ksantynoksydaznoi aktyvnosti reaktsii tymusa shchuriv. Visnyk KNU im Tarasa Shevchenka, 28 (in Ukrainian).

Mitarev, D. N. (2009). Rannyaya diagnostika beremennosti sviney metodom immunofermentnogo analiza (YFA): avtoref. diss. na soisk. nauch. stepeni kand. vet. nauk: 16.00.07. Krasnodar, 19 (in Russian).

Ogbodo, S. O., Okaka, A. N., Nwagha, U. I., \& Ejezie, F. E. (2014). Free Radicals and Antioxidants Status in Pregnancy: Need for Pre- and Early Pregnancy Assessment. Am. J. Med. and Med. Sc., 4(6), 230-235. doi: 10.5923/j.ajmms.20140406.06.

Patil, S. B., Kodliwadmath, M. V., \& Kodliwadmath, S. M. (2006). Lipid peroxidation and nonenzymatic antioxidants in normal pregnancy. J. Obstet Gynecol India, 56(5), 399-401.

Purdey, M. S., Connaughton, H., \& Whiting, S. (2015). Boronate probes for the detection of hydrogen peroxide release from human spermatozoa. Free Radic Biol Med, 81, 69-76. doi: 10.1016/j.freeradbiomed.2015.01.015.

Romanenko, V. N., \& Boyko, Y. A. (2015) Hormonokorriguriyushchie svoystva synteticheskoho tymogena pri stimulyatsiy vosproyzvodytelnoi funktsiy u svinomatok. Vestnik Krasnodarskogo HAU, 4, 144-149 (in Russian).

Rybalko, V. P. (2005) Suchasni metodyky doslidzhen u svynarstvi. Poltava, 114-123 (in Ukrainian).

Shabunin, S. V. (2010). Metodicheskiye polozheniya po izucheniyu protsessov svobodnoradykalnoho okisleniya $\mathrm{v}$ sisteme antioksydantnoy zashchity organizma. Voronezh, 3637; 51-52 (in Russian).

Shostya, A. M., Stupar, I. I., Usenko, S. O., Bondarenko, O. M., Tsybenko, V. G., Chukhlib, Ye. V., \& Slynko, V. G. (2019). Reproduktyvni yakosti svynok riznykh porid. Veterynariia, tekhnolohii tvarynnytstva ta pryrodokorystuvannia, 3, 230236. doi: 10.31890/vttp.2019.03.31 (in Ukrainian). 
Stupar, I. I. (2018) Prooksydantno-antyoksydantnyi homeostaz u svynok u rizni fazy statevoho tsyklu. Visnyk Poltavskoi derzhavnoi ahrarnoi akademii, 4, 178-184. doi: 10.31210/visnyk2018.04.28 (in Ukrainian).

Usenko, S. O., Shostya, A. M., \& Tsybenko, V. G. (2016) Osoblyvosti dynamiky estradiolu-17 $\beta$ v krovi svynei riznoi stati, viku ta fiziolohichnoho stanu. Tavriiskyi naukovyi visnyk, 96, 165-169 (in Ukrainian).

Usenko, S. O., Shostya, A. M., Stoyanovskyy, V. G., Tenditnyk, V. S., Birta, G. O., Kravchenko, O. I., \& Kuzmenko, L. M. (2020). Influence of vitamins on the prooxidant-antioxidant homeostasis in boars under the conditions of heat stress. Ukrainian Journal of Veterinary and Agricultural Sciences, 3(2), 30-35. doi: 10.32718/ujvas3-2.05.

Velichko, A. K., Solovyev, V. B., \& Henhyn, T. (2009). Metody laboratornogo opredeleniya obshchey perekys razrushaishchey aktyvnosty fermentov rasteniy. Yzv. Penzenskoho hos. ped. un-ta, 14(18), 44-48 (in Russian).

Villamor, E., Moreno, L., \& Mohammed, R. (2019) Reactive oxygen species as mediators of oxygen signaling during fetal-to-neonatal circulatory transition. Free Radical Biology and Medicine, 142. 82-96. doi: 10.1016/j.freeradbiomed.2019.04.008. 